\title{
Contrasting evidence for corticosteroid treatment for coronavirus-induced cytokine storm
}

Hong Kong Med J 2020;26:269-71

https://doi.org/10.12809/hkmj208517

To the Editor-Two recent articles concerning corticosteroid usage in the coronavirus disease 2019 (COVID-19) pandemic provide opposing evidence and run the risk of muddying the waters on this controversial yet important topic. ${ }^{1,2}$ On the one hand, Russell et $\mathrm{al}^{1}$ tabulated a number of mainly observational clinical studies cautioning more harm than benefit with corticosteroid usage. On the other hand, Shang et $\mathrm{al}^{2}{ }^{2}$ acknowledging that existing evidence is inconclusive at best, referenced recommendations by Chinese physicians with frontline clinical experiences of COVID-19 who advocate short courses of corticosteroids at low-tomoderate doses for more severe disease.

In clinical settings, physicians tend to use corticosteroids only for treating critically ill patients. Therefore, selection bias and confounders in observational studies might contribute to any observed increased mortality in patient groups treated with corticosteroids. The papers cited by Russell et $\mathrm{al}^{1}$ omit to address coronavirus mortality, and the strength of the evidence presented does not support the certainty of the authors' conclusions (Table).

Similar to respiratory viral diseases such as the seasonal influenza, two categories of people seem susceptible to die from COVID-19: older adults, especially those with chronic disease or other comorbidities, and seemingly healthy adults with exacerbated autoinflammatory syndrome termed the cytokine storm syndromes. ${ }^{3-5}$ On the contrary, children and infants seem to survive epidemics of

TABLE. Adapted from cases reported by Russell et al' with counter comments

\begin{tabular}{|c|c|c|}
\hline Virus & Outcomes of corticosteroid therapy & Counter comments \\
\hline \multirow[t]{2}{*}{ MERS-CoV } & \multirow{2}{*}{$\begin{array}{l}\text { Delayed clearance of viral RNA from } \\
\text { respiratory tract }\end{array}$} & Not significantly associated to 90-day mortality \\
\hline & & Not about SARS-CoV-2 \\
\hline \multirow[t]{3}{*}{ SARS-CoV } & \multirow[t]{3}{*}{ Delayed clearance of viral RNA from blood } & No relevant mortality and morbidity data \\
\hline & & $\begin{array}{l}\text { Small sample size: } 9 \text { patients received early hydrocortisone vs } 7 \\
\text { patients received placebo }\end{array}$ \\
\hline & & Not about SARS-CoV-2 \\
\hline \multirow[t]{3}{*}{ SARS-CoV } & \multirow[t]{3}{*}{ Complication: psychosis } & No relevant mortality and morbidity data \\
\hline & & Small sample size: only 15 patients with SARS-related psychosis \\
\hline & & Not about SARS-CoV-2 \\
\hline \multirow[t]{3}{*}{ SARS-CoV } & \multirow[t]{3}{*}{ Complication: diabetes } & No relevant mortality data \\
\hline & & $\begin{array}{l}\text { Study was comparing SARS patients receiving different dosages } \\
\text { of methylprednisolone }\end{array}$ \\
\hline & & Not about SARS-CoV-2 \\
\hline \multirow[t]{2}{*}{ SARS-CoV } & \multirow{2}{*}{$\begin{array}{l}\text { Complication: avascular necrosis in } \\
\text { survivors }\end{array}$} & No relevant mortality data \\
\hline & & Not about SARS-CoV-2 \\
\hline \multirow[t]{3}{*}{ Influenza virus } & \multirow[t]{3}{*}{ Increased mortality } & No relevant mortality and morbidity data \\
\hline & & $\begin{array}{l}\text { Significant statistical heterogeneity in the analysis of the effect of } \\
\text { corticosteroids on mortality }\end{array}$ \\
\hline & & Not about SARS-CoV-2 \\
\hline \multirow[t]{3}{*}{ RSV } & \multirow[t]{3}{*}{ No clinical benefit in children } & No relevant data on mortality and morbidity \\
\hline & & $\begin{array}{l}\text { Study was on children with bronchiolitis, a disease of a different } \\
\text { pathophysiology }\end{array}$ \\
\hline & & Not about SARS-CoV-2 \\
\hline
\end{tabular}

Abbreviations: MERS-CoV = Middle East respiratory syndrome-related coronavirus; RSV = respiratory syncytial virus; SARS-CoV = severe acute respiratory syndrome coronavirus 
coronavirus infections with very mild disease. ${ }^{6}$

We acknowledge the potential risks associated with high-dose corticosteroids in treating COVID-19 pneumonia, and agree that corticosteroid usage should be avoided if there are other efficacious anti-inflammatory immunomodulating medications against the cytokine storm, such as intravenous immunoglobulin, interleukin-1 inhibitors, interleukin-6 inhibitors, and Janus kinase inhibitors. ${ }^{4}$ However, on the basis of recommendations by frontline Chinese physicians and local clinical experience during the severe acute respiratory syndrome epidemic, a short course of corticosteroids at low-to-moderate dose is probably justifiable for critically ill patients with hyperinflammation. ${ }^{7,8}$ Chinese researchers are running a prospective randomised controlled trial to review the efficacy and safety of corticosteroids. ${ }^{9}$ Until further evidence becomes available, whether to use corticosteroids or not remains controversial.

\section{Author contributions}

All authors contributed to the concept of the study, acquisition and analysis of the data, drafting of the manuscript, and critical revision of the manuscript for important intellectual content. All authors had full access to the data, contributed to the study, approved the final version for publication, and take responsibility for its accuracy and integrity.

\section{Conflicts of interest}

The authors have no conflicts of interest to disclose.

\section{Funding/support}

This letter received no specific grant from any funding agency in the public, commercial, or not-for-profit sectors.

\footnotetext{
${ }^{1}$ Karen KY Leung, MB, BS, MRCPCH

${ }^{1} \mathrm{KL}$ Hon *, MB, BS, MD

${ }^{2}$ SY Qian, MD
}

\section{${ }^{1}$ Frankie WT Cheng, MB, ChB, MD}

Department of Paediatrics and Adolescent Medicine, The Hong Kong Children's Hospital, Hong Kong

2 Pediatric Intensive Care Unit, Beijing Children's Hospital, Capital Medical University, National Center for Children's Health, China

*Corresponding author: ehon@hotmail.com

\section{References}

1. Russell CD, Millar JE, Baillie JK. Clinical evidence does not support corticosteroid treatment for 2019-nCoV lung injury. Lancet 2020;395:473-5.

2. Shang L, Zhao J, Hu Y, Du R, Cao B. On the use of corticosteroids for 2019-nCoV pneumonia. Lancet 2020;395:683-4.

3. Novel Coronavirus Pneumonia Emergency Response Epidemiology Team. The epidemiological characteristics of an outbreak of 2019 novel coronavirus diseases (COVID19) in China [in Chinese]. Zhonghua Liu Xing Bing Xue Za Zhi 2020;41:145-51.

4. Mehta P, McAuley DF, Brown M, Sanchez E, Tattersall RS, Manson JJ, et al. COVID-19: consider cytokine storm syndromes and immunosuppression. Lancet 2020;395:1033-4.

5. Ng PC, Lam CW, Li AM, Wong CK, Cheng FW, Leung TF, et al. Inflammatory cytokine profile in children with severe acute respiratory syndrome. Pediatrics 2004;113:e7-14.

6. Hon KL, Leung CW, Cheng WT, Chan PK, Chu WC, Kwan YW, et al. Clinical presentations and outcome of severe acute respiratory syndrome in children. Lancet 2003;361:1701-3.

7. Zhao JP, Hu Y, Du RH, Chen ZS, Jin Y, Zhou M, et al. Expert consensus on the use of corticosteroid in patients with 2019-nCoV pneumonia [in Chinese]. Zhonghua Jie He He Hu Xi Za Zhi 2020;43:183-4.

8. Yam LY, Lau AC, Lai FY, Shung E, Chan J, Wong V, et al. Corticosteroid treatment of severe acute respiratory syndrome in Hong Kong. J Infect 2007;54:28-39.

9. US National Library of Medicine, US Government. Efficacy and Safety of Corticosteroids in COVID-19. Available from: https://clinicaltrials.gov/ct2/show/NCT04273321. Accessed 24 Mar 2020. 